\title{
A role for cAMP-dependent protein kinase A in early Dictyostelium development
}

\author{
Richard A. Firtel ${ }^{1}$ and Autumn L. Chapman \\ Department of Biology, Center for Molecular Genetics, University of California, San Diego, La Jolla, California 92093 USA
}

\begin{abstract}
In Dictyostelium, cAMP functions as an extracellular regulatory molecule that controls aggregation, expression of a number of classes of genes, and cellular differentiation by binding to cell-surface receptors that activate intracellular signal transduction pathways. To investigate possible roles for intracellular cAMP, we have overexpressed the wild-type mouse type-I regulatory subunit $\left(R_{I}\right)$ of cAMP-dependent protein $C(P K A)$ in Dictyostelium cells, as well as mutant forms of the subunit that are altered in their ability to bind cAMP. We show that overexpression of a mutated $R_{I}$, which lacks both cAMP-binding sites and presumably forms a complex with the endogenous Dictyostelium catalytic subunit that cannot be activated by cAMP, results in cells that do not aggregate or express sets of genes that are normally induced in the multicellular stages. Transformations that express the mutant subunit at low levels show no observable phenotype. We show that these cells can respond to pulses of cAMP and activate cAMP receptor/G protein-mediated processes, including the activation of adenylate and guanylate cyclases and the induction of a class of genes known to be regulated through the receptor-mediated pathways; however, the cells do show an altered pattern of expression of other genes normally active during the preaggregation/interphase and aggregation stages. Of interest is a substantial overexpression of the developmentally regulated PDE mRNA. Cell lines carrying constructs encoding the wildtype subunit or mutant subunits lacking one of the two binding sites show no visual phenotype. The results suggest that PKA-mediated functions, presumably controlled by increases in intracellular cAMP, are essential for Dictyostelium aggregation.
\end{abstract}

[Key Words: Dictyostelium; cAMP-dependent protein kinase A; gene regulation]

Received July 17, 1989; revised version accepted October 30, 1989.

Dictyostelium discoideum grows as a single-cell vegetative amoeba that initiates a multicellular developmental cycle upon starvation. After $\sim 3-4 \mathrm{hr}$ of interphase, cells within a population begin to secrete pulses of cAMP at 5- to 6-min intervals. Adjacent cells respond in two ways: (1) They chemotax toward the cAMP signal, and (2) they activate a relay pathway in which cAMP is secreted into the medium. This secreted cAMP can then interact with and activate cells lying farther from the aggregation center. The pulsatile signaling results in an outward relay of cAMP and an inward movement of cells toward the aggregation center. These two responses are controlled by two kinetic classes of cell-surface cAMP receptors. Class A (fast-dissociating) receptors are coupled to adenylate cyclase through a $G$ protein and several other factors that have been defined genetically or biochemically; class B (slow-dissociating) receptors are believed to be coupled to phospholipase $C$ and guanylate cyclase through another $G$ protein. The $B$ class controls both chemotaxis and regulation of the expression of two classes of genes: a class induced by cAMP pulses and a class repressed by cAMP pulses (Janssens

${ }^{1}$ Corresponding author. and van Haastert 1987; Mann and Firtel 1987; Mann et al. 1988; Firtel et al., 1989). A number of the cAMP pulse-induced genes have been cloned and encode proteins that are essential for aggregation, including the cAMP receptor, the $G_{\alpha}$ protein subunit coupled to the class B receptors, and a serine esterase (Klein et al. 1988; Kumagai et al. 1989b; Pupillo et al. 1989; Rubino et al. 1989).

In addition to those classes of genes described above, the expression of a number of other genes is regulated, at least in part, by cAMP during early development. These include the induction of the cell surface and secreted forms of cAMP phosphodiesterase, possible repression of synthesis of the cAMP phosphodiesterase inhibitor discoidin I (a lectin with functions analogous to both the fibronectins in metazoan cells), and the gene M4-1 (Berger and Clark 1983; Franke et al. 1987; Kimmel and Carlisle 1986; Kessin 1988). In this last case, it is believed that the repression of expression of this gene requires a rise in intracellular cAMP.

Dictyostelium also contains a cAMP-dependent protein kinase A (PKA); however, the functional role of this enzyme in growth and development is not understood (de Gunzberg and Veron 1982; de Gunzberg et al. 1984; Leichtling et al. 1984; Majerfeld et al. 1984). Expression 
of the regulatory subunit is developmentally controlled, being expressed at low levels in vegetative cells and increasing in level during development (de Gunzberg et al. 1986). This developmental increase suggests that PKA has a role in controlling developmental processes (Leichtling et al. 1984; de Gunzberg et al. 1986). Overexpression of the Dictyostelium R subunit results in cells that do not aggregate (Simon et al. 1989). In mammalian cells, cAMP acts predominantly as a second messenger through PKA (Walsh et al. 1968). This process involves the regulation of a number of metabolic processes and the activation of gene expression through several DNAbinding proteins, including the CREB protein /Clegg et al. 1987; Hoeffler et al. 1988; Riabowol et al. 1988; Yamamoto et al. 1988; Gonzalez et al. 1989; Mellon et al. 1989). Although Dictyostelium has a nuclear protein that has affinity for the mammalian cAMP response element (CRE) (I. Rajagopal and R.A. Firtel, unpubl.), no genes are known that have this element as part of their cis-acting regulatory sequences.

Inactive PKA in metazoans is comprised of a complex of two catalytic and two regulatory subunits. The regulatory subunit is capable of binding 2 moles of cAMP in sites designated $\mathrm{A}$ and $\mathrm{B}$. CAMP binding to these sites results in the release of the catalytic subunit, rendering it active as a kinase (see Taylor et al. 1988). In Dictyos. telium, the regulatory subunit does not have a dimerization site, and the holoenzyme consists of one of each of the two subunits (de Gunzberg et al. 1984; Majerfeld et al. 1984; Chevalier et al. 1986).

It has been shown previously that the Dictyostelium catalytic subunit can form a dimer with the mammalian regulatory subunit (Chevalier et al. 1986). We have made use of this fact to approach the possible function of the Dictyostelium enzyme in early development. In Dictyostelium cells, we have overexpressed the mouse wild-type type-I regulatory subunit and mutant forms that are missing either or both of the cAMP-binding sites. In mammalian cells, expression of the mutant subunits results in a PKA that cannot be activated; thus, regulatory pathways controlled by cAMP are constitutively repressed (see Discussion; Clegg et al. 1987; Woodford et al. 1989). We have overexpressed cDNAs encoding these proteins in Dictyostelium cells and have shown that expression of the form lacking both CAMPbinding sites inhibits aggregation. The mutant forms that lack only one of the binding sites do not have this effect, nor does the wild-type form. In these transformants, we have also studied the effect on the cAMP and cGMP signal transduction pathways mediated through the cell-surface cAMP receptors and the expression of a number of classes of genes expressed early in development. The results presented here indicate that the enzyme has an essential role in early development and that it does not appear to significantly alter pathways mediated through the cAMP receptor.

\section{Results}

The mouse PKA wild-type type-I regulatory subunit $\left(R_{I}\right)$ and the mutations that are missing either or both of the $A$ and $B$ cAMP-binding sites $\left(R_{I} A^{-}, R_{I^{-}} B^{-}, R_{1} A^{-} B^{-}\right)$were obtained from $G$. Stanley McKnight. Because the vast majority of known Dictyostelium-coding regions have a series of As in front of the ATG initiation codon, we thought that it was important to modify the region around the mouse $\mathrm{R}_{\mathrm{I}}$ subunit initiation codon to have a more Dictyostelium-like sequence (Kimmel and Firtel 1983; Warrick 1987). Using oligonucleotide-directed mutagenesis, a series of A residues preceded by a HindIII site was placed immediately in front of the ATG of a clone of the mouse $R_{I}$ (see Materials and methods). In addition, the second codon of the mammalian gene is an alanine codon that is rarely used in Dictyostelium. Because it may be important for efficient translation initiation that the second codon be one frequently used in Dictyostelium and, thus, presumably one for which the tRNA is moderately abundant, this codon was changed from GCG to GCT. The modified $\mathrm{R}_{\mathrm{I}}$ cDNA clone was inserted into the Dictyostelium expression vector BS18 downstream from the Actin 15 promoter /Kumagai et al. $1989 \mathrm{~b}$ ), which is expressed at very high levels in vegetative cells and in early development (Knecht et al. 1986). Figure 1 shows the relevant features of this construct and the sequence around the ATG. Similar constructs were made with $\mathrm{R}_{\mathrm{I}} \mathrm{A}^{-}, \mathrm{R}_{\mathrm{I}} \mathrm{B}^{-}$, and $\mathrm{R}_{\mathrm{I}} \mathrm{A}^{-} \mathrm{B}^{-}$clones. These were each transformed into wild-type Dictyostelium cells, and stable transformants were selected. Populations were obtained for six independent transformations for the $\mathrm{R}_{\mathrm{I}} \mathrm{A}^{-} \mathrm{B}^{-}$vector and four independent transformations for the wild-type $R_{I}, R_{I} A^{-}$and $R_{I} B^{-}$vectors.

\section{Morphological phenotypes of $R_{I}$ transformants}

To determine developmental phenotype, populations of transformants were plated on nutrient agar plates in association with bacteria to obtain clonal isolates. As the Dictyostelium cells digest the bacteria, they form a 'plaque,' or clearing, in the bacterial lawn that continues to grow outward as more of the bacteria are eaten by the dividing Dictyostelium cells. Each plaque is a cloned colony initiated by single Dictyostelium cells. As the bacterial food source is depleted, the Dictyostelium cells at the center of the colony initiate development, morphological changes of the developing Dictyostelium can be readily observed, and morphological phenotypes of clones can be scored. Approximately 50-100 individual clones were examined for each of the transformations. All clones carrying a control vector (the vector without a regulatory subunit insert) or vectors expressing the wild-type, the $\mathrm{R}_{\mathrm{I}} \mathrm{A}^{-}$, or $\mathrm{R}_{\mathrm{I}} \mathrm{B}^{-}$subunits developed normally. In contrast, $35 \%$ of clones presumably expressing the $\mathrm{R}_{\mathrm{I}} \mathrm{A}-\mathrm{B}-$ form did not aggregate at all, and $\sim 10-15 \%$ either aggregated poorly or formed sectors as the colonies grew with a region that did not aggregate and a region that produced small aggregates. For comparison, Figure 2 shows a photograph of a colony of a control aggregation-deficient strain (Agip53) (Darmon et al. 1975) (Fig. 2A) and normal developing clones (wild-type phenotype) (Fig 2B). A ridge is seen in the outer edges in 


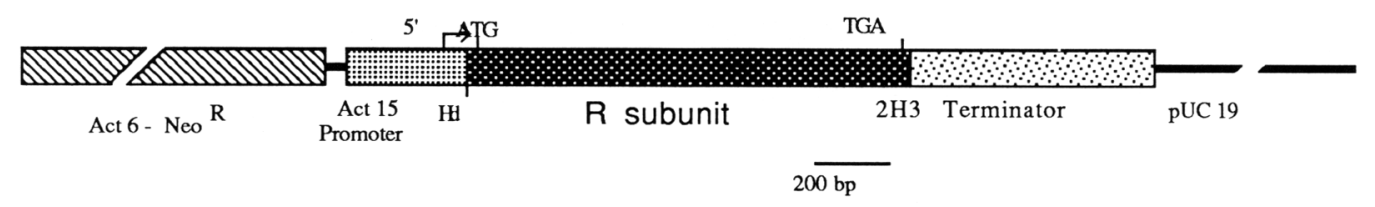

\author{
AAGCTTAAAAA ATG GCT \\ HindIII Met Ala
}

Figure 1. Map of construct used to express mouse wild-type and mutant $R_{I}$ subunits. The sequence surrounding the ATG initiation codon is shown (for details, see text and Materials and methods).

many clones and represents the boundary between the vegetative Dictyostelium cells and the bacterial lawn. It contains both bacteria being eaten and Dictyostelium cells. In the center of Figure 2, B /cells in the center start developing first, as they have depleted the food first), mature fruiting bodies can be seen. In addition, one can observe other developmental stages, including migrating slugs (see legend to Fig. 2). Figure 3 shows the detailed phenotype of some of the aggregation-deficient $\mathrm{R}_{\mathrm{I}} \mathrm{A}^{-} \mathrm{B}^{-}$ clones, along with clones that show normal development. Figure 3, B shows an aggregation-deficient clone, the center of which is identified by an open arrow. As can be seen, there is a smooth lawn of cells with no aggregation phenotype. The concentric 'ridges' (small solid arrowheads) represent the perimeter of the clone and identify the edge of the uneaten bacterial lawn. The perimeter of another colony is seen in the lower right area of Figure 3B. Figure 3, A and C, shows an aggregation-deficient (center indicated by an open arrow) and an adjacent wild-type clone (solid arrowheads). In both cases, the mutant (aggregation-deficient) and normal (wildtype developing/clones have expanded within the bacterial lawn until they touch. Because the bacterial food is now exhausted in this area, neither clone can expand further. In contrast to the aggregation-deficient clones, the wild-type clones show multicellular aggregates that are developing normally, similar to those seen in Figure 2B. Figure 3D shows a clone that has formed a sector. Approximately five-sixths of the center of the clone is aggregation-deficient (open arrow). A pie-shaped sector [solid arrowhead (a)] containing relatively small aggregates that represent poorly aggregating cells has formed. As the clone enlarges, many of the outer cells have aggregated and formed a ring around the undeveloped cells in the center [solid arrowhead (b)]. This is generally caused by a loss of plasmid or a reduction in copy number, as the cells are not under G418 selection when grown on nutrient agar in association with bacteria. We have previously reported this observation for the mutant phenotypes caused by a high level of expression of a Dictyostelium ras- $\mathrm{Thr}_{12}$ gene on an integrating plasmid. Sectoring resulted from a reduction in the copy number in some cells (Reymond et al. 1986).

When the aggregation-deficient clones were picked and grown in axenic medium and then replated on nutrient agar in association with bacteria, $>95 \%$ of the subclones were aggregation-deficient. Of these, sec- ondary clones were then picked and used for subsequent experiments. In the case of the clones that sectored, the regions that aggregated gave clones that developed normally, whereas the regions that did not originally aggregate yielded cells which, when replated, produced both aggregation-deficient and wild-type clones. A fraction of the clones that did not aggregate produced clones that

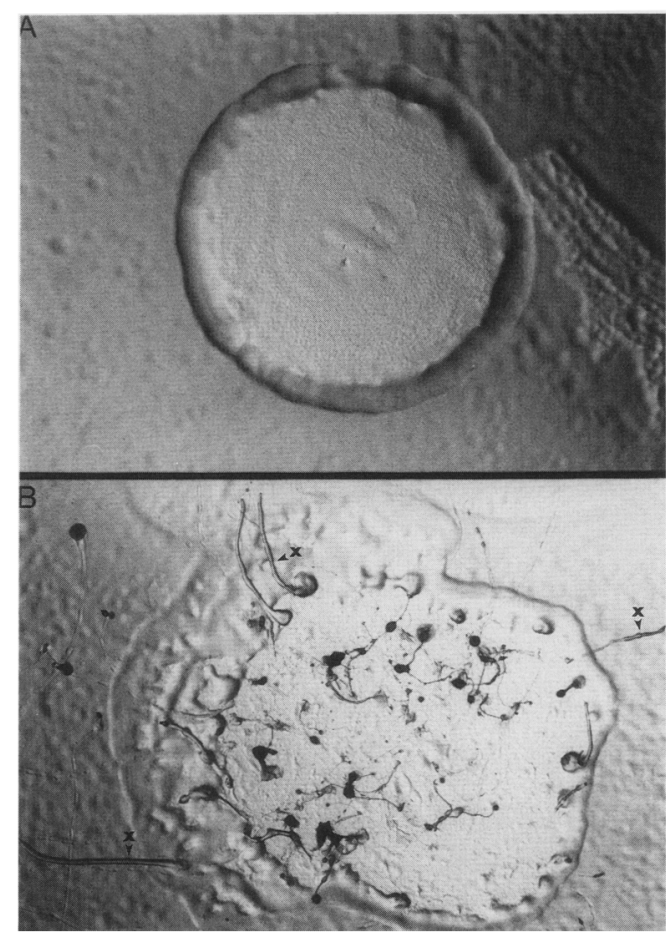

Figure 2. Photographs of wild-type and aggregation-deficient clones. $(A)$ Photograph of section of nutrient agar plate with a Dictyostelium colony from the aggregation-deficient strain Agip53 grown in association with bacteria (see Materials and methods). $(B)$ Colonies of wild-type cells. The two colonies are seen as a clearing in the bacterial lawn. For the wild-type clone, development initiates as the food is depleted. Thus, the cells in the center of the expanding (a result of the eating of the bacteria and multiplication by cell division) colony are the oldest, have depleted their food first, and show the older stages of development. For the nonaggregating strain, no visible development is seen. $(B)$ An arrowhead $(x)$ marks migrating slugs, some of which are migrating out of the zone of the clone. The diameter of the clone in $A$ was $1.1 \mathrm{~cm}$. 


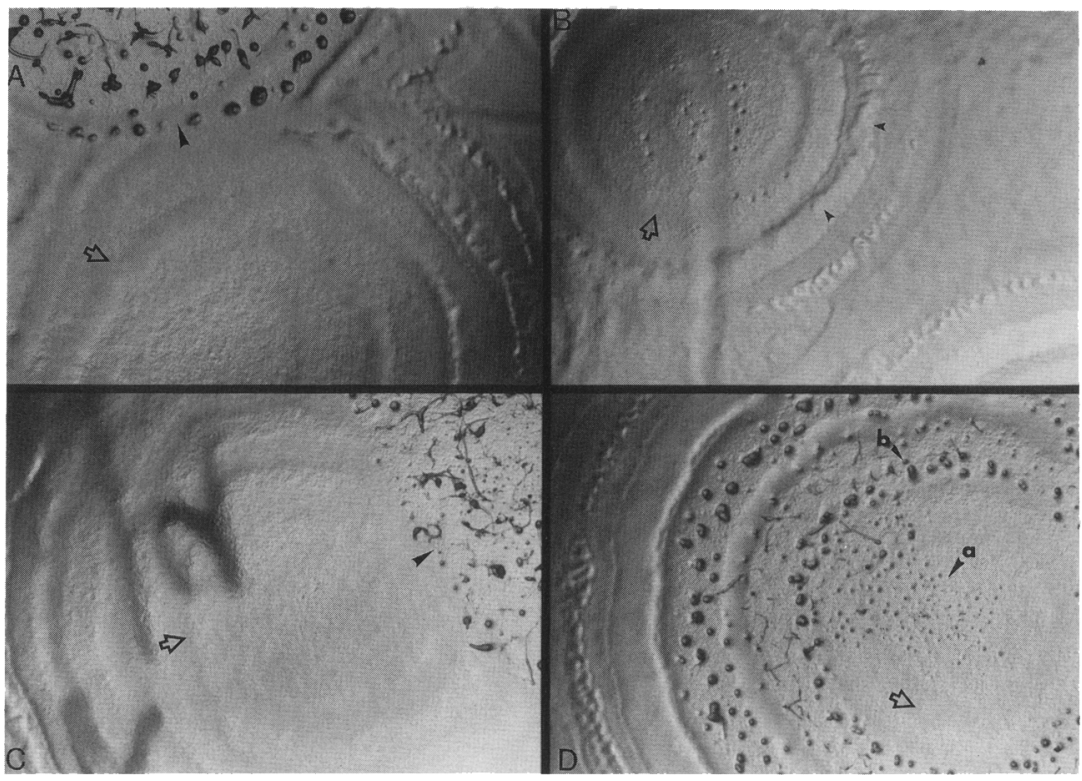

Figure 3. Phenotype of $R_{1} A^{-} B^{-}$clones. Photographs of single clones on $S M / 3$ agar plates are shown. Cells were grown in association with bacteria (see Materials and methods). $(A, B$, and $C)$ Aggregation-deficient clones; $(B)$ the border between the Dictyostelium and the bacterial lawn; $(D)$ a clone that is aggregation-deficient in the central region (open arrow), with a sector showing aggregation [arrowhead (a)]. The outer cells of the clone have developed [arrowhead $(b)] A$ and $C$ also show wild-type clones (see large arrowheads) that are adjacent to the aggregation-deficient cells.

sectored, suggesting that these represented clones in which the expression of the mutant regulatory subunit was relatively unstable. The above results suggest a direct correlation of the aggregation-deficient phenotype with the expression of clones encoding the $\mathrm{R}_{\mathrm{I}} \mathrm{A}^{-} \mathrm{B}^{-}$subunit that is unable to bind cAMP.

We also examined the developmental phenotype of cells that were grown in axenic medium under G418 selection and plated for development on non-nutrient agar or on black Millipore filters in Mes-PDF (buffered salts). $\mathrm{R}_{\mathrm{I}} \mathrm{A}^{-} \mathrm{B}^{-}$cells plated on black Millipore filters showed no development at $20 \mathrm{hr}$, whereas wild-type cells aggregated at $8-10 \mathrm{hr}$ and began to form mature culminants by $20 \mathrm{hr}$. By $30 \mathrm{hr}, \mathrm{R}_{\mathrm{I}} \mathrm{A}^{-} \mathrm{B}^{-}$clones produced a few small knobs within the population, suggestive of the beginnings of aggregation centers. Development did not proceed further. On non-nutrient agar, we observed no development by $10 \mathrm{hr}$, at which time the wild-type cells had aggregated, and, by $20 \mathrm{hr}$, a few aggregation centers had formed, which produced several very small fruiting bodies by $30 \mathrm{hr}$ (see Fig. 4A; wild-type cells are in Fig. 4B). The number and the size of fruiting bodies were small, and $<5 \%$ of the cell population participated in aggregation. The remainder of the cells that had not formed aggregates by this time did not aggregate, even if the plates were allowed to sit for another $24 \mathrm{hr}$.

To investigate the stability of the phenotypes, clones were grown for various periods of time, and then their ability to form aggregation-competent clones was assayed. After growth for 1-2 weeks in axenic growth medium containing $10 \mu \mathrm{g} / \mathrm{ml} \mathrm{G} 418,90 \%$ of the clones were still aggregation-deficient, whereas after $\sim 8$ weeks, $\sim 70 \%$ of the clones did not form aggregates. All of the subsequent experiments were performed using sec- ondary clones that had been grown for only 2 weeks. These clones were frozen and were used to start new primary cultures at later times.

To obtain some insight to possible effects of production of $\mathrm{R}_{\mathrm{I}} \mathrm{A}^{-} \mathrm{B}^{-}$in vegetative growing cells, we determined the growth rate of $R_{I} A^{-} B^{-}$transformants in relation to control KAx-3 cells or cells transformed with a control vector. No differences in the growth rate were observed (data not shown). We also examined the level of expression of two developmentally regulated genes that are also expressed during growth, and no differences were observed (see, Figs. 7 and 8, below).

To gain insight to possible differences in the phenotype observed for different $R_{1} A^{-} B^{-}$clones, we examined the levels of Act $15 / R_{1} A^{-} B^{-}$mRNA in RNA isolated from vegetative cells and cells $6 \mathrm{hr}$ after the initiation of development (6-hr cells) of clones showing a strong mutant phenotype or those showing a wild-type phenotype. Figure 5A shows RNA blots of randomly selected $\mathrm{R}_{\mathrm{I}} \mathrm{A}^{-} \mathrm{B}^{-}$clones that showed either an aggregation-deficient or wild-type phenotype. As can be seen, RNA from four $\mathrm{R}_{\mathrm{I}} \mathrm{A}^{-} \mathrm{B}^{-}$aggregation-deficient clones, designated $A-D$, shows a high level of expression of the Act15/ $\mathrm{R}_{\mathrm{I}} \mathrm{A}^{-} \mathrm{B}^{-}$RNA, whereas clones having wild-type phenotype (E-G) showed a substantially lower level of expression. In addition, clones expressing a high level of the Act $15 / R_{I}$ Act $15 / R_{I} A^{-}$, or Act $15 / R_{I^{-}} B^{-}$transcription, which show a wild-type developmental phenotype, are also shown. Untransformed cells show no hybridization (KAx-3). The results suggest a direct correlation between the level of expression of the $A c t 15 / R_{I} A^{-} B^{-}$transcripts and the aggregation-deficient phenotype. Differences in the level of an expressed gene between transformed clones are common in Dictyostelium and are apparently 


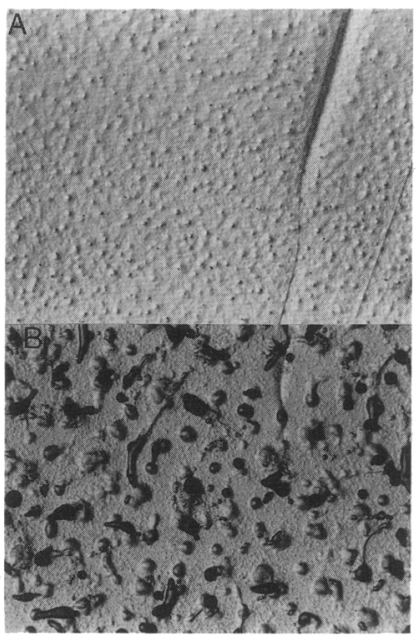

Figure 4. Phenotype of $R_{I} A^{-} B^{-} / A$ clone on non-nutrient agar. Clone $\mathrm{R}_{\mathrm{I}} \mathrm{A}^{-} \mathrm{B}-/ \mathrm{A}|A|$ and wild-type $\mathrm{KAx}-3(B)$ cells were grown in axenic media, washed, and plated on agar containing $12 \mathrm{mM}$ $\mathrm{Na}^{+} / \mathrm{K}^{+}$phosphate buffer $(\mathrm{pH}$ 6.1). (A) $22 \mathrm{hr}$ after starvation; $(B)$ $15 \mathrm{hr}$ after starvation.

related to vector copy number (Nellen and Firtel 1985; Reymond et al. 1986; Ahern et al. 1988). In addition, these results show that the lack of phenotype of cells transformed with the wild-type $R_{I}$ clone and $R_{I} A^{-}-B^{-}$ clones is not attributable to the lack of expression of the gene fusions.

Integrating vectors are normally present in $10-200$ copies per cell and, generally, expression levels are proportional to copy number (Nellen and Firtel 1985). This range can be skewed upwards by selecting clones at higher G418 concentrations. When cells were selected at $20 \mu \mathrm{g} / \mathrm{ml} \mathrm{G} 418$ instead of $10 \mu \mathrm{g} / \mathrm{ml}$, a higher percentage of cells were aggregation-deficient. If these cells are placed at $50 \mu \mathrm{g} / \mathrm{ml} \mathrm{G} 418,>80 \%$ of the viable cells form clones that are aggregation-deficient.

To determine whether the regulatory subunit was actually being expressed in the $\mathrm{R}_{\mathrm{I}} \mathrm{A}^{-} \mathrm{B}^{-}$transformants, Western blots were carried out using protein extracts from some of the same clones with a rabbit polyclonal antibody against a mammalian regulatory subunit. Results in Figure 5B show that $\mathrm{R}_{1} \mathrm{~A}^{-} \mathrm{B}^{-}$clones $\mathrm{A}$ and $\mathrm{B}$, which show a mutant phenotype, have high levels of a protein with the same molecular weight as the marker mammalian $R_{I}$ subunit, whereas clones $E-G$, which show a wild-type phenotype, express substantially low levels of the mutant $R_{\mathrm{I}}$. KAx-3 cells show no band at this position. Moreover, the $\mathrm{R}_{\mathrm{l}}, \mathrm{R}_{\mathrm{I}} \mathrm{A}^{-}$, and $\mathrm{R}_{\mathrm{I}} \mathrm{B}^{-}$clones that showed high gene fusion RNA expression also showed high protein levels, indicating that mammalian $\mathrm{R}$ subunit protein was being expressed.

\section{Effect of $R_{I}$ expression on cAMP receptor-mediated signal transduction}

Chemotaxis assays (see Materials and methods) were also done to examine the ability of $\mathrm{R}_{\mathrm{I}} \mathrm{A}^{-} \mathrm{B}^{-}$cells to ag- gregate toward cAMP. Although these assays are qualitative in nature, our results indicated that the $\mathrm{R}_{1} \mathrm{~A}^{-} \mathrm{B}^{-}$ transformants showed very little chemotaxis to cAMP in comparison to control untransformed cells (data not shown).

A possible biochemical basis for the aggregation-deficient phenotype is that expression of $R_{I} A^{-} B^{-}$results in an inhibition of cAMP-activated cell-surface receptormediated signal transduction processes. cAMP receptormediated signal transduction processes are essential for mediating chemotaxis during aggregation and are required for the activation of expression of a class of early genes required for morphological development. cAMP class A receptor-mediated events are assayed by quantitating cAMP-mediated activation of adenylate cyclase, whereas cAMP class B receptor-mediated events are assayed by quantitating the activation of guanylate cyclase (see Janssens and van Haastert 1987; Firtel et al. 1989). Activation of adenylate and guanylate cyclases in response to added cAMP was assayed on cells that were starved for either $5 \mathrm{hr}$ at $20^{\circ} \mathrm{C}$ or $16 \mathrm{hr}$ at $6^{\circ} \mathrm{C}$ from three

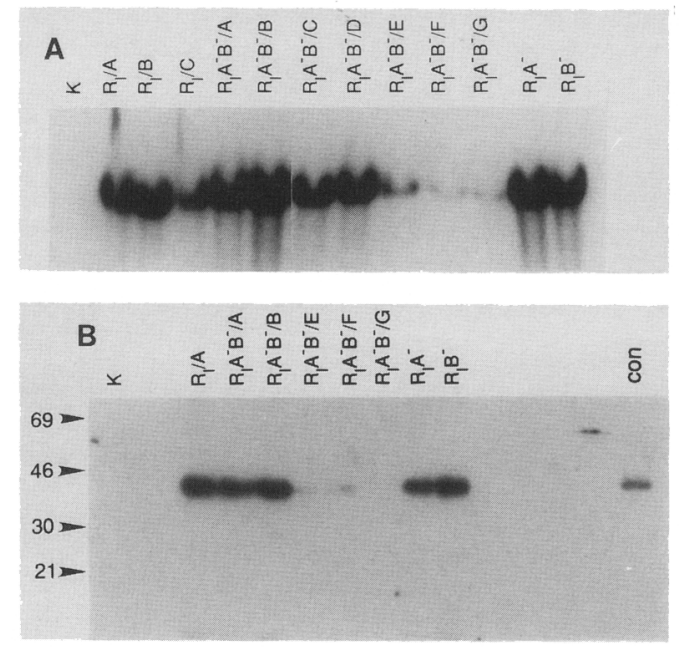

Figure 5. Expression of $\mathrm{R}_{\mathrm{I}}$ in transformants. $(A) \mathrm{RNA}$ blot of wild-type and mutant Act $15 / R_{I}$ construct expression. RNA was isolated from log-phase vegetatively growing $\mathrm{KAx}-3$ control cells and seven individual $\mathrm{R}_{\mathrm{I}} \mathrm{A}^{-} \mathrm{B}^{-}$clones; four gave an aggregation-deficient phenotype $\left(R_{I} A-B-/ A-D\right)$, and three gave a wildtype morphological phenotype $\left(\mathrm{R}_{\mathrm{I}} \mathrm{A}-\mathrm{B}-\mathrm{E}-\mathrm{G}\right)$. In addition, RNA from an $R_{I}, R_{I} A^{-}$, and $R_{I} B^{-}$clones are shown. Filters were probed with a gel-purified restriction fragment carrying the $R_{I^{-}}$ coding region that was labeled using random primer method with Klenow fragment of DNA polymerase I (for details, see Materials and methods). (B) Western blot of $\mathrm{R}_{\mathrm{I}} \mathrm{A}^{-} \mathrm{B}^{-}$in transformants. Vegetative cells from control untransformed KAx-3 $(\mathrm{K})$ and clones $\mathrm{R}_{\mathrm{I}} \mathrm{A}, \mathrm{R}_{\mathrm{I}} \mathrm{A}^{-}, \mathrm{R}_{\mathrm{I}} \mathrm{B}^{-}, \mathrm{R}_{\mathrm{I}} \mathrm{A}^{-} \mathrm{B}^{-} / \mathrm{A}-\mathrm{B}$, and $\mathrm{R}_{\mathrm{I}} \mathrm{A}^{-} \mathrm{B}-\mathrm{E}-\mathrm{G}$ (extracts from $R_{I} A^{-} B^{-} / C-D$, were not available) used for the RNA blot were lysed and sized on $12 \%$ SDS-polyacrylamide gels, blotted, and probed with antibody against regulatory subunit. A marker lane (con) containing purified $R_{I}$ is shown. The extracts from untransformed cells $(\mathrm{K})$ and marker lane (con) were placed several lanes away from the experimental samples to prevent possible contamination. In each lane, $35 \mu \mathrm{g}$ of protein was run. (Left) Numbers represent stained molecular weight markers run on the same gel. 
separate $\mathrm{R}_{\mathrm{I}} \mathrm{A}^{-} \mathrm{B}^{-}$clones in three independent experiments and were compared to the activation observed in control cells. Wild-type cells starved under these conditions are at the early stages of aggregation and are referred to as 'aggregation-competent' cells. As can be seen in the results shown in Figure 6 for $\mathrm{R}_{\mathrm{I}} \mathrm{A}^{-} \mathrm{B}^{-}$and control cells for one of these experiments (cells starved for $16 \mathrm{hr}$ at $6^{\circ} \mathrm{Cl}$, there is negligible difference in the kinetics and level of activation of either adenylate or guanylate cyclase in mutant transformants compared to control cells. These results indicate that this aspect of the signaling and chemotaxis system are not impaired under these conditions. When aggregation-competent cells were obtained by plating at high density for $5 \mathrm{hr}$ at $20^{\circ} \mathrm{C}$, the level of adenylate and guanylate cyclase activation was slightly reduced $(\sim 75 \%)$ compared to that of control cells (data not shown).

We looked at the ability of the cells to respond to

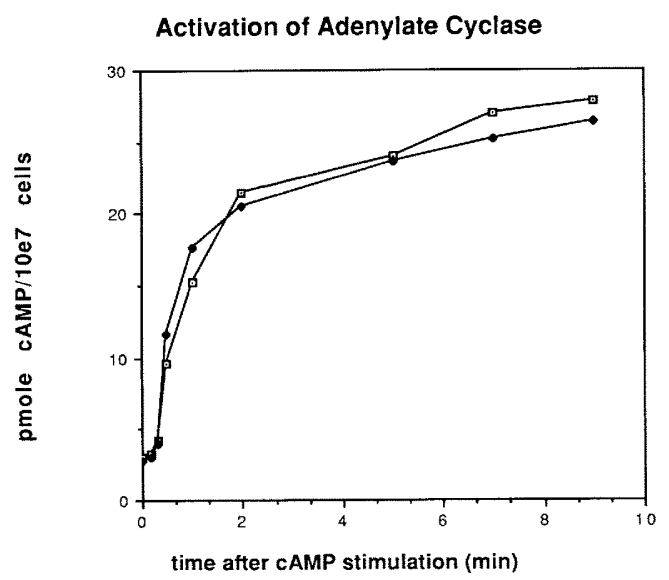

Activation of Guanylate Cyclase

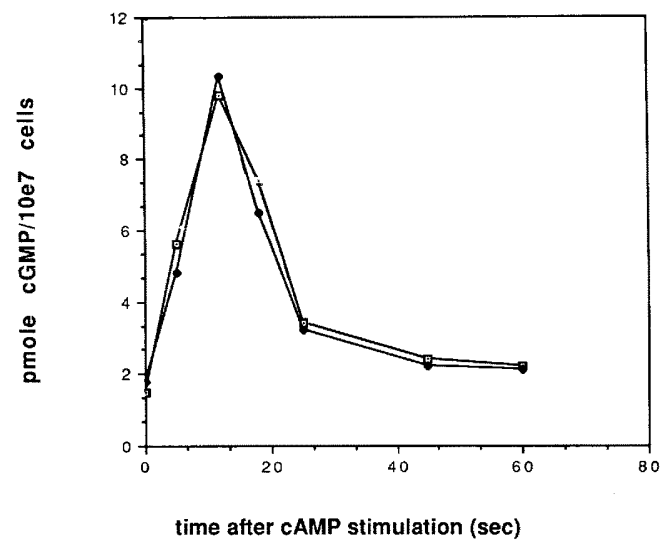

Figure 6. Activation of adenylate and guanylate cyclase. Vegetative cells from wild-type strain $\mathrm{KAx}-3$ and transformant $R_{I} A-B-/ A$ were washed and plated on non-nutrient agar at $6^{\circ} \mathrm{C}$ for $16 \mathrm{hr}$. The cells were washed and assayed for the activation of adenylate cyclase, using deoxy-cAMP /which stimulates the receptor but does not interfere with cAMP assayl, and guanylate cyclase, using cAMP, according to the procedures referenced in Materials and methods. The results are plotted as picomoles per $10^{7}$ cells. ( $\left.\square\right) \mathrm{KAx}^{-} 3$; $\left(\mathrm{R}_{\mathrm{I}} \mathrm{A}^{-} \mathrm{B}^{-}\right.$.
cAMP by inducing either aggregation-stage pulse-induced genes or an early prestalk-enriched gene that is inducible by high continuous levels of cAMP (Mehdy et al. 1983; Mann and Firtel 1987). Expression of both classes of genes by cAMP has been shown to involve specific cAMP cell-surface receptor-mediated pathways but does not require the relay pathway involving the activation of adenylate cyclase (Schaap and van Driel 1985; Gomer et al. 1986; Schaap et al. 1986; Kimmel 1987; Mann and Firtel 1987; Mann et al. 1988; Kumagai et al. 1989a,b). Four pulse-induced genes were examined: D2 encoding a serine esterase required for early development (Mann and Firtel 1987; Rubino et al. 1989); the cAMP receptor gene (Klein et al. 1988); $G_{\alpha} 2$, the $G_{\alpha}$ protein subunit that is coupled to the class $B$ cAMP receptors (Kumagai et al. 1989a; Pupillo et al. 1989); and contact sites A, a protein involved in cell-cell adhesion during later development [(see Gerisch et al. 1985) for D2, see Fig. 7; other data not shown]. In all four cases, the genes are expressed at extremely low levels in vegetative cells and at moderate levels in starved cells at $5 \mathrm{hr}$ in shaking culture in the absence of added cAMP [these cultures have endogenous CAMP oscillations (Mann and Firtel 1987)]. When the cells are pulsed with cAMP, all four genes are expressed at normal levels in the control cells and are overexpressed by two- to threefold in three independent $\mathrm{R}_{\mathrm{I}} \mathrm{A}^{-} \mathrm{B}^{-}$aggregation-deficient clones from different transformations. If the cells treated with $25 \mathrm{nM}$ pulses of cAMP are then given high levels of (300 cAMP $\mu \mathrm{M}$ ) for $5 \mathrm{hr}$, the expression of all four genes is repressed (data not shown), as expected from previous results (Mann et al. 1988; Mann and Firtel 1989). These results not only suggest that the aggregation-deficient phenotype is not the result of inhibition of genes known to be required for aggregation (D2, receptor, $\left.G_{\alpha} 2\right)$ but also show that these genes are overexpressed in these cells.

pst-cathepsin (cysteine proteinase 2) is a gene whose product is preferentially localized in the anterior prestalk cells during early slug formation and whose expression is inducible by high levels of cAMP (Mehdy et al. 1983; Pears et al. 1985; Datta et al. 1986; Gomer et al. 1986). When cells that have been pulsed are given high concentrations of cAMP, this gene is expressed at similar levels in control cells and in the three $\mathrm{R}_{\mathrm{I}} \mathrm{A}^{-} \mathrm{B}^{-}$transformants (data not shown). The results indicate that in shaking culture, $\mathrm{R}_{\mathrm{I}} \mathrm{A}^{-} \mathrm{B}^{-}$cells are capable of responding to cAMP and inducing the expression of this gene.

We also plated the $\mathrm{R}_{\mathrm{I}} \mathrm{A}^{-} \mathrm{B}^{-}$cells for development and examined the expression of pst-cathepsin at $15 \mathrm{hr}$ of development, when it is maximally expressed in control cells in tipped aggregates. The $\mathrm{R}_{\mathrm{I}} \mathrm{A}^{-} \mathrm{B}^{-}$transformants showed a level of mRNA accumulation that was only $10-20 \%$ that of the control cells (data not shown). We do not interpret these results to indicate that cAMP-dependent PKA is required for the expression of this gene under these conditions. Instead, we feel that lack of expression is the result of a pleiotropic effect of the cells having not proceeded through the appropriate developmental stages to induce the expression of these genes, which normally occurs in multicellular aggregates. 


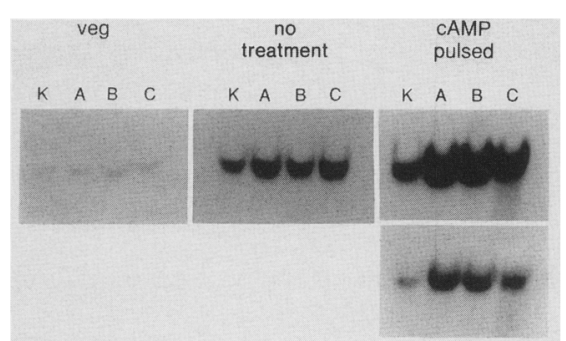

Figure 7. Expression of pulse-induced genes. The expression of the $\mathrm{D} 2$ pulse-induced gene is shown in control cells $(\mathrm{K})$ and $\mathbf{R}_{I} A^{-} B^{-}$transformants $A, B$, and $C$. The three panels represent RNA isolated from vegetative cells, starved cells, and cells shaken in buffered salts for $5 \mathrm{hr}$ at $5 \times 10^{6} \mathrm{cells} / \mathrm{ml}$, either in the absence of added exogenous cAMP or pulsed with $25 \mathrm{nM}$ cAMP. Note that although wild-type cells have endogenous oscillations of cAMP in shaking culture and express D2 and other pulse-induced genes, exogenous pulsing stimulates this expression. Moreover, the increase in pulse-induced gene expression requires cAMP activation of the cAMP cell-surface receptors (Mann and Firtel 1987; Mann et al. 1988). Details and methods are cited in Materials and methods. The top line shows that blots all hybridized together at the same exposure. The bottom line (pulsed cAMP) is the same blot but autoradiographed for a shorter time period to more readily show the differences between the control cells and the transformants.

\section{Regulation of preaggregation genes}

We have also investigated the regulation of two other genes, discoidin I and cAMP phosphodiesterase (PDE). Expression of both genes is controlled, in part, by cAMP, although the pathway by which cAMP regulates their expression is unknown (Yeh et al. 1978; Lappano and Coukell 1982; Berger and Clark 1983; Lacombe et al. 1986; Coukell and Cameron 1987; Franke et al. 1987; Podgorski et al. 1989). Discoidin I is encoded by a threemember gene family. Discoidin I mRNAs are expressed at moderate levels in axenically grown cells and increase to maximal levels during aggregation; their levels then decrease (Rowekamp et al. 1980; Poole et al. 1981; Devine et al. 1982). PDE is expressed as a constitutive 1.9kb mRNA in growth and development and a $2.4-\mathrm{kb}$ developmentally regulated mRNA (Franke et al. 1987; Podgorski et al. 1989).

Figure 8 shows the expression of discoidin I and PDE under the conditions described for the pulse-induced genes. Discoidin I is expressed at high levels in vegetative cells and cells shaken without treatment from all strains, although the level in $\mathrm{R}_{\mathrm{I}} \mathrm{A}^{-} \mathrm{B}^{-}-\mathrm{C}$ is slightly lower. In response to cAMP pulses or pulses followed by high, continuous levels of cAMP, all of the $\mathrm{R}_{\mathrm{I}} \mathrm{A}^{-} \mathrm{B}^{-}$ strains show a substantial reduction in discoidin I mRNA levels compared to control cells.

All strains have an approximately equal level of the 1.9-kb PDE constitutive mRNA in vegetative cells. When cells are shaken without treatment, a condition that probably mimics the cAMP oscillations seen in these cells when they are plated on agar, there is a substantial overexpression of the $2.4-\mathrm{kb}$ developmental
mRNA in the $\mathrm{R}_{\mathrm{I}} \mathrm{A}^{-} \mathrm{B}^{-}$strains compared to control cells, whereas the level of the $1.9-\mathrm{kb}$ mRNA is approximately the same in all strains. When cells are pulsed with cAMP, the $\mathrm{R}_{\mathrm{I}} \mathrm{A}^{-} \mathrm{B}^{-}$strains still show a higher level of the 2.4-kb PDE mRNA compared to KAx-3, but the difference between that seen for the $\mathrm{R}_{\mathrm{I}} \mathrm{A}^{-} \mathrm{B}^{-}$strains and $\mathrm{KAx}-3$ is not as great. When the pulsed cells are then given high levels of cAMP, the differences between the strains are even less: $\mathrm{KAx}-3$ and $\mathrm{R}_{\mathrm{I}} \mathrm{A}^{-} \mathrm{B}^{-}-\mathrm{B}$ have approximately the same levels of the 2.4-kb PDE mRNA, whereas $R_{I} A^{-} B^{-}-A$ has two- to threefold higher levels. When the cells are plated on filters and harvested at $6 \mathrm{hr}$ into development, the PDE mRNA profiles are similar to those in the shaking culture without treatment /data not shown). These results suggest that there are substantial differences in the regulation of both discoidin I and PDE in the $\mathrm{R}_{\mathrm{I}} \mathrm{A}^{-} \mathrm{B}^{-}$strains compared to control untransformed cells. Also of interest is that expression of one gene is enhanced, whereas the other is repressed.

\section{Discussion}

The results described here suggest that cAMP-dependent PKA plays an essential role in Dictyostelium development. An aggregation-deficient phenotype is observed when a mutant regulatory subunit $\left(\mathrm{R}_{\mathrm{I}} \mathrm{A}-\mathrm{B}^{-}\right)$that is incapable of binding cAMP in either of its two sites (A and $\mathrm{B}$ ) is expressed in transformed Dictyostelium cells at relatively high levels. Clones that express the Act $15 / \mathrm{R}_{\mathrm{I}} \mathrm{A}^{-}$

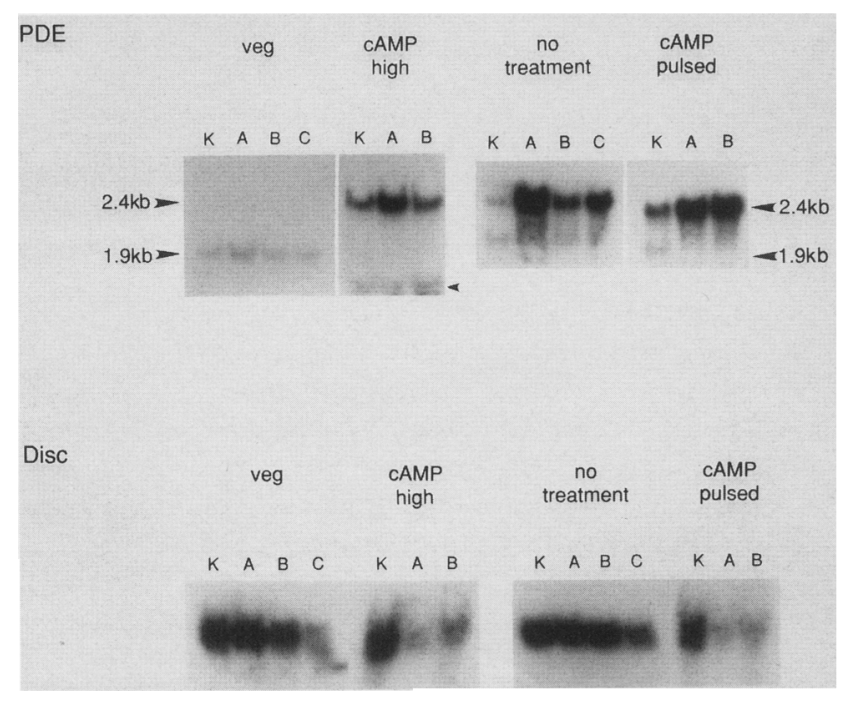

Figure 8. Regulation of discoidin and PDE. The same RNAs used in Fig. 7 were also blotted and hybridized for discoidin I mRNA (This is encoded by three genes producing slightly different sized mRNAs and thus yielding a very broad band) and PDE mRNA. In addition, cells were pulsed with cAMP for $5 \mathrm{hr}$, followed by the addition of $300 \mu \mathrm{M}$ cAMP for an additional $5 \mathrm{hr}$. Note that high $(300 \mu \mathrm{M})$ cAMP levels result in the adaptation and downregulation of the chemotactic cAMP receptors. PDE expression has been shown previously to be activated by both cAMP pulses and the presence of continuous cAMP levels (for references, see text). The 1.9- and 2.4-kb PDE mRNAs are indicated. The small arrowhead indicates the 17S rRNA band. 
$B^{-}$fusion gene RNA and, subsequently, the $R_{I} A^{-} B^{-}$ subunit, at relatively low levels show no observable phenotype. These results therefore give a direct correlation between the level of $\mathrm{R}_{\mathrm{I}} \mathrm{A}^{-} \mathrm{B}^{-}$protein in the cell and the aggregation-deficient phenotype. Expression of the wildtype regulatory subunit(s) that is mutant in one of the two binding sites shows no observable morphological phenotype, even though the fusion gene is expressed at high levels. When the $R_{I} A^{-} B^{-}$subunit is expressed in mammalian cells, the cells are nonresponsive to cAMP, and basal levels of expression of cAMP-induced genes are repressed.

In mammalian cells, phenotypes are observed by expressing the $\mathrm{R}_{\mathrm{I}} \mathrm{A}^{-}$or $\mathrm{R}_{\mathrm{I}} \mathrm{B}^{-}$forms, but they are not as strong as those observed from expressing the $\mathrm{R}_{\mathrm{I}} \mathrm{A}^{-} \mathrm{B}^{-}$ form (Clegg et al. 1987; Mellon et al. 1989; Woodford et al. 1989). It is also known that $\mathrm{R}_{\mathrm{I}} \mathrm{A}^{-}, \mathrm{R}_{\mathrm{I}} \mathrm{B}^{-}$, and $\mathrm{R}_{\mathrm{I}} \mathrm{A}^{-} \mathrm{B}^{-}$ will associate with the mammalian catalytic $(C)$ subunit in vitro. The $\left(\mathrm{R}_{\mathrm{I}} \mathrm{A}^{-}\right)_{2} \mathrm{C}_{2}$ and $\left(\mathrm{R}_{\mathrm{I}} \mathrm{B}^{-}\right)_{2} \mathrm{C}_{2}$ holoenzymes can be activated by cAMP but the $\left(\mathrm{R}_{\mathrm{I}} \mathrm{A}^{-} \mathrm{B}^{-}\right)_{2} \mathrm{C}_{2}$ form cannot (Clegg et al. 1987; Woodford et al. 1989). Moreover, the wild-type mammalian regulatory subunit can associate with the Dictyostelium catalytic subunit in vitro /Chevalier et al. 1986), and we assume that our phenotype is the result of to an association of the mutant regulatory subunit with Dictyostelium catalytic subunit in vivo. At sufficient levels of the mutant $\mathrm{R}_{\mathrm{I}} \mathrm{A}^{-} \mathrm{B}^{-}$subunit, we expect that much of the endogenous catalytic subunit would be present in a complex that could not be activated by cAMP. We feel that this is probably the basis of the observed phenotype. In support of this, we do observe a higher level of Act15/regulatory subunit mRNA and $\mathrm{R}_{\mathrm{I}} \mathrm{A}^{-} \mathrm{B}^{-}$protein in cells with a strong aggregationdeficient phenotype.

Other workers have overexpressed the wild-type regulatory subunit of the Dictyostelium cAMP-dependent PKA (Simon et al. 1989). They observed a similar aggregation-deficient phenotype and a pattern of expression of cysteine protease 1 (CP1) that is similar to that observed for $p s t$-cathepsin (cysteine protease 2), a gene that is coordinately expressed with CP1. They also observed that their phenotype is dependent on the level of expressed $R$ subunit. The mechanism by which overexpression of the endogenous regulatory subunit produces a phenotype is not known but may be a result of titrating out intracellular cAMP by presenting a large number of cAMPbinding sites or by shifting the equilibrium between free and bound catalytic subunit. Because the number of regulatory subunits is expected to be substantially higher than the amount of catalytic subunits in these cells, one would expect that a large fraction of the catalytic subunit therefore would be associated with the regulatory subunits that have not bound CAMP. Of interest is the fact that we do not see a phenotype when the mammalian wild-type subunit is overexpressed in Dictyostelium; however, neither these cells nor the transformants obtained by Simon et al. (1989) have been analyzed in sufficient biochemical detail to postulate differences between our results with the mouse wild-type $R_{I}$ clone and those obtained by Simon and collaborators with the Dic- tyostelium $\mathrm{R}$ subunit. We also do not know the relative in vivo binding affinities of the Dictyostelium catalytic subunit for the Dictyostelium or mammalian regulatory subunit or the fraction of the catalytic subunit that is active in these cells in vivo. Unfortunately, the Dictyostelium holoenzyme dissociates into free $\mathrm{R}$ and $\mathrm{C}$ subunits when cells are lysed (Majerfeld et al. 1984), which precludes assaying the levels of active $\mathrm{C}$ subunit in extracts.

When cells from clones that do not form aggregates on nutrient agar are plated on non-nutrient substrates, a few very small aggregates are formed. We have shown that the class A and class B cAMP receptor-mediated pathways function in these cells. Both adenylate cyclase, coupled to the class A pathway, and guanylate cyclase, coupled to the class $B$ receptors, can be activated to normal levels in response to cAMP. However, the chemotaxis assays indicated that the cells did not respond well to cAMP. Because this assay is very qualitative in nature, we can only say that the cells do not respond as well to a cAMP concentration gradient as wild-type cells do. Pulse-induced genes, also mediated by the class B pathway, appear to have normal kinetics and are overexpressed in these cells. Therefore, at present we cannot account for the aggregation-deficient phenotype by an effect on the known intracellular signal transduction pathways that are mediated through the cell-surface cAMP receptors.

The effects of $\mathrm{R}_{\mathrm{I}} \mathrm{A}^{-} \mathrm{B}^{-}$expression on discoidin $\mathrm{I}$ and PDE expression were greater: Discoidin I mRNA levels were substantially reduced in $\mathrm{R}_{\mathrm{I}} \mathrm{A}^{-} \mathrm{B}^{-}$cells that received pulses of cAMP, whereas the developmentally induced PDE mRNA was very high in shaking cells that received no treatment or that were pulsed with cAMP or in cells developed on filters. It is known that overexpression of the PDE will block development, and our aggregationdeficient phenotype could be consistent with the high PDE mRNA levels (Faure et al. 1988). However, we do not know whether expression of the $\mathrm{R}_{\mathrm{I}} \mathrm{A}^{-} \mathrm{B}^{-}$is also affecting other functions to cause the block in aggregation.

Our results do suggest that normal cAMP-dependent protein kinase is required for development and is involved in some essential regulatory pathway, possibly that controlling PDE expression. The PKA-mediated events may involve a pathway downstream of the receptor-mediated signal transduction pathway or may involve control of genes other than those that have been described above. In mammalian cells, PKA regulates a large number of cellular functions, including those controlling cellular metabolism. Interestingly, we observe no effect on growth rate nor on the level of expression of discoidin I and PDE in growing cells, although the expression of both genes is affected during development. The results suggest that inhibition of development by $\mathrm{R}_{\mathrm{I}} \mathrm{A}^{-} \mathrm{B}^{-}$expression does not appear to result from a general inhibition of cellular metabolism. Moreover, our observations that some genes are overexpressed and that adenylate cyclase and guanylate cyclase activations are normal also suggest that general metabolic processes are not being generally affected. 
Also of interest is the fact that Synag mutants, which are incapable of activating adenylate cyclase and thus do not have an increase in intracellular cAMP in response to cAMP binding to the receptor, are capable of aggregating in response to a cAMP signal. It is known that adenylate cyclase activity, as measured in the presence of $\mathrm{Mn}^{2+}$, increases in early development, and this could result in an increase in nonreceptor-stimulated intracellular cAMP levels that could then activate PKA. It is thus possible that some of the roles of CAMP in the cell are not mediated by increases in intracellular CAMP that result from cAMP receptor activation of adenylate cyclase. It is possible that an increase in the level of cAMP and cAMP-dependent protein kinase in these cells during early development is necessary for proper aggregation. Additional studies are necessary to elucidate the functional role of the specific pathway in which PKA activity is essential for early Dictyostelium development.

\section{Materials and methods}

\section{Constructs}

A cDNA clone carrying the mouse type-I cAMP-dependent PKA regulatory subunit $\left(R_{I}\right)$ and clones encoding mutant regulatory subunits lacking the A, B, or the A and B cAMP-binding sites were obtained from G. Stanley McKnight (Clegg et al. 1987; Woodford et al. 1989|. Because endogenous Dictyostelium genes expressed at high levels have multiple A residues immediately $5^{\prime}$ to the ATG, we used oligonucleotide-directed mutagenesis, using the Amersham mutagenesis kit, to insert a HindIII site, followed by $5 \mathrm{~A}$ residues $5^{\prime}$ to the ATG of the wild-type mouse $\mathrm{R}_{\mathrm{I}} \mathrm{cDNA}$ clone. In addition, the second codon encoding alanine was changed from GCG to GCT at the same time.

To make similar constructs with the cDNAs encoding the three mutant $R_{I}$ forms, we made use of the unique BglII site that lies within the $\mathrm{R}_{\mathrm{I}}$ gene and $5^{\prime}$ to the $\mathrm{A}$ and $\mathrm{B}$ cAMP-binding sites. We cloned the $5^{\prime}$ portion of the modified wild-type $R_{I}$ from the added HindIII site to the BgIII site onto the $3^{\prime}$ portion of the three mutant $\mathrm{R}_{\mathrm{I}}$ cDNAs, using the unique $B g$ III site. This yielded four $R_{I}$ clones-the wild-type, the $A^{-}$, the $B^{-}$, and the $A^{-} B^{-}$forms - all of which had a modified 5 ' end. Doublestranded DNA sequencing confirmed the sequences.

The modified cDNAs were inserted into the unique HindIII site of the expression vector BS18 $\cdot 2 \mathrm{H} 3 / \mathrm{HindIII}$ that contains an actin 15 promoter with a HindIII site inserted within the Actin $155^{\prime}$ untranslated region (Kumagai et al. 1989b; A. Kumagai and R.A. Firtel, unpubl.; see Fig. 1). Downstream from the HindIII site is the terminator from the SP70 spore coat protein gene clone designated $2 \mathrm{H} 3$ /S. Datta and R.A. Firtel, unpubl.). This is inserted into a vector carrying an actin $6-$ neo $^{R}$ gene fusion that confers G418 resistance to Dictyostelium cells (Nellen et al. 1984).

\section{General methods}

Dictyostelium cells were grown in HL5 axenic medium containing oxoid proteose peptone and Difco yeast extract, as described previously (Datta and Firtel 1987). Cells were transformed by electroporation (Howard et al. 1988; Dynes and Firtel 1989 ) and selected at 10 or $20 \mu \mathrm{g} / \mathrm{ml} \mathrm{G418}$, as described in Results.

To isolate the single clones, the transformed cells were plated at a variety of dilutions on SM/3 nutrient agar plates in association with Klebsiella aerogenes (Ahern et al. 1988). After 2-3 days, clones were seen initially as small clearings in the bacterial lawn. After an additional 1-2 days, clones were sufficiently large for observation, and those clones capable of developing showed aggregates forming at the center of the area cleared of bacteria. As the clones continued to grow, development proceeded from the center outward, starting with the Dictyoste lium cells that first depleted their bacterial food source. Phenotypes could be observed after a total of 3-5 days. Clones were picked into Petri plates containing HL5 medium with antibodies, using sterile toothpicks. After growth for $12-16 \mathrm{hr}$, the medium was supplemented with G418 at the appropriate concentration.

Cells were developed either in starved shaking culture in Mes-PDF or on solid substrates (Millipore filters or non-nutrient agar), as described previously (Mehdy et al. 1983; Mehdy and Firtel 1985; Mann and Firtel 1987). Some aliquots of cells in shaking culture were pulsed with $25 \mathrm{nM}$ cAMP or given high continuous levels of cAMP, as described previously (Mehdy et al. 1983; Mehdy and Firtel 1985; Mann and Firtel 1987).

RNA and DNA were isolated from transformed cultures (Datta and Firtel 1988; Nellen et al. 1987). RNA was size-fractionated on denaturing agarose gels, blotted to nylon membrane, and poured with radio-labeled, gel-purified restriction fragments containing the appropriate gene sequence (Mann and Firtel 1987). DNA isolated from transformants (Firtel et al. 1985) was digested with restriction enzymes, size-fractionated on agarose gels, blotted, and probed, as described above. Western blotting was performed as described by Harlow and Lane (1988).

PDE cDNA was a gift of J. Franke and R. Kessin and has been described previously (Lacombe et al. 1986). Receptor cDNA was a gift of P. Devreotes and has been described previously (Klein et al. 1988).

\section{cAMP, CGMP, and chemotactic assays}

Chemotaxis assays to cAMP were performed as described by Segall et al. (1987). Measurement of cGMP levels in response to cAMP was assayed according to van Haastert (1984, 1985), using the cGMP assay kit from Amersham. cAMP was assayed according to van Haastert $(1984,1985)$, using purified PKA obtained from S. Taylor (University of California, San Diego). For these assays, $10^{8}$ to $2 \times 10^{8}$ cells were plated on non-nutrient agar and placed at $6^{\circ} \mathrm{C}$ for $16 \mathrm{hr}$ or $20^{\circ} \mathrm{C}$ for $5 \mathrm{hr}$. These cells are described as aggregation-competent cells (van Haastert 1984, 1985). Western blot protein was electrotransferred to Millipore at $25 \mathrm{~V}$ for $10 \mathrm{hr}$ at $4^{\circ} \mathrm{C}$. The rabbit antibody [1/4000 dilution of $\left(\mathrm{NH}_{4}\right)_{2} \mathrm{SO}_{4}$ of serum] was first incubated in the presence of $5 \%$ dried skim milk with a blot containing cell extracts from untransformed cells. The solution was then removed and incubated with the experimental blot. After washing, 125I-labeled protein A (ICN) was used to localize proteins interacting with the antibody.

\section{Acknowledgments}

We thank G. Stanley McKnight for supplying cDNA clones of the wild-type and mutant PKA type-I regulatory subunit, purified regulatory subunit, and anti-regulatory subunit antibodies, Susan Taylor for supplying the anti-regulatory subunit antibodies and purified PKA, J. Franke and R. Kessin for PDE cDNA, and P. Devreotes for cAMP receptor cDNA. We are indebted to A. Kumagai for assistance with some of the cAMP and cGMP assays. We thank M. Veron and J. Williams for com- 
municating their results prior to publication and S. Mann for helpful comments on the manuscript. This work was supported by U.S. Public Health Service grants to R.A.F.

\section{References}

Ahern, K.G., P.K. Howard, and R.A. Firtel. 1988. Identification of regions essential for extrachromosomal replication and maintenance of an endogenous plasmid in Dictyostelium. Nucleic Acids Res. 16: 6825-6837.

Berger, E.A. and J.M. Clark. 1983. Specific cell-cell contact serves as the developmental signal to deactivate discoidin I gene expression in Dictyostelium discoideum. Proc. Natl. Acad. Sci. 80: 4983-4987.

Chevalier, M., J. de Gunzberg, and M. Veron. 1986. Comparison of the regulatory and catalytic subunits of cAMP dependent protein kinase from Dictyostelium discoideum and bovine heart using polyclonal antibodies. Biochem. Biophys. Res. Commun. 136: 651-656.

Clegg, C.H., L.A. Correll, G.G. Cadd, and G.S. McKnight. 1987. Inhibition of intracellular cAMP-dependent protein kinase using mutant genes of the regulatory type I subunit. J. Biol. Chem. 262: 13111-13119.

Coukell, M.B. and A.M. Cameron. 1987. Effects of calcium antagonists on cyclic AMP phosphodiesterase induction in Dictyostelium discoideum. I. Cell Sci. 88: 379-388.

Darmon, M., P. Brachet, and L.H. Pereira da Silva. 1975. Chemotactic signals induce cell differentiation in Dictyostelium discoideum. Proc. Natl. Acad. Sci. 72: 3163-3116.

Datta, S., R. Gomer, and R.A. Firtel. 1986. Spatial and temporal regulation of a foreign gene by a prestalk-specific promoter in transformed Dictyostelium discoideum cells. Mol. Cell Biol. 6: 811-820.

Datta, S. and R.A. Firtel. 1988. An 80 base pair cis-acting regulatory region controls cAMP and developmental regulation of a prestalk gene in Dictyostelium. Genes Dev. 2: 294-304.

de Gunzberg, J. and M. Veron. 1982. A cAMP-dependent protein kinase is present in differentiating Dictyostelium discoideum cells. EMBO I. 1: 1063-1068.

de Gunzberg, J., J. Franke, R.H. Kessin, and M. Veron. 1986. Detection and developmental regulation of the mRNA for the regulatory subunit of the cAMP-dependent protein kinase of $D$. discoideum by cell-free translation. EMBO $I$. 5: $363-367$.

de Gunzberg, J., D. Part, N. Guiso, and M. Veron. 1984. An unusual adenosine $3^{\prime} / 5^{\prime}$-phosphate dependent protein kinase from Dictyostelium discoideum. Biochemistry 23: 38053812 .

Devine, J.M., A.S. Tsang, and J.G. Williams. 1982. Differential expression of the members of the Discoidin I multigene family during growth and development of Dictyostelium discoideum. Cell 28: 793-800.

Dynes, J.L. and R.A. Firtel. 1989. Molecular complementation of a genetic marker in Dictyostelium using a genomic DNA library. Proc. Nat1. Acad. Sci. 86: 7966-7970.

Faure, M., G.J. Podgorski, J. Franke, and R.H. Kessin. 1988. Disruption of Dictyostelium discoideum morphogenesis by overproduction of cAMP phosphodiesterase. Proc. Natl. Acad. Sci. 85: 8076-8080.

Firtel, R.A., C. Silan, T.E. Ward, P. Howard, B.A. Metz, W. Nellen, and A. Jacobson. 1985. Extrachromosomal replication of shuttle vectors in Dictyostelium discoideum. Mol. Cell. Biol. 5: 3241-3250.

Firtel, R.A., P.J.M. van Haastert, A.R. Kimmel, and P.N. Devreotes. 1989. G protein linked signal transduction pathways in development: Dictyostelium as an experi- mental system. Cell 58: 235-239.

Franke, J., G.J. Podgorski, and R.H. Kessin. 1987. The expression of two transcripts of the phosphodiesterase gene during the development of Dictyostelium discoideum. Dev. Biol. 124: $504-511$.

Gerisch, G.M., J. Hagmann, P. Hirth, C. Rossier, U. Weinhart, and M. Westphal. 1985. Early Dictyostelium developmental control mechanisms bypassed by sequential mutagenesis. Cold Spring Harbor Symp. Quant. Biol. 50: 813-822.

Gomer, R.H., D. Armstrong, B.H. Leichtling, and R.A. Firtel. 1986. cAMP induction of prespore and prestalk gene expression in Dictyostelium is mediated by the cell-surface cAMP receptor. Proc. Natl. Acad. Sci. 83: 8624-8628.

Gonzalez, G.A., K.K. Yamamoto, W.H. Fischer, D. Karr, P. Menzel, W. Biggs III, W.W. Vale, and M.R. Montminy. 1989. A cluster of phosphorylation sites on the cyclic AMP-regulated nuclear factor CREB predicted by its sequence. Nature 337: 749-752.

Harlow, E. and D. Lane. 1988. Antibodies: A laboratory manual. Cold Spring Harbor Laboratory Press, Cold Spring Harbor, New York.

Hoeffler, J.P., T.E. Meyer, Y. Yun, J.L. Jameson, and J.F. Haberner. 1988. Cyclic AMP-responsive DNA-binding protein: Structure based on a cloned placental cDNA. Science 242: 1430-1433.

Howard, P.K., K.G. Ahern, and R.A. Firtel. 1988. Establishment of a transient expression system for Dictyostelium discoideum. Nucleic Acids Res. 16: 2613-2623.

Janssens, P.M.W. and P.J.M van Haastert. 1987. Molecular basis of transmembrane signal transduction in Dictyostelium discoideum. Microbiol. Rev. 51: 396-418.

Kessin, R.H. 1988. Genetics of early Dictyostelium discoideum development. Microbiol. Rev. 52: 29-49.

Kimmel, A.R. 1987. Different molecular mechanisms for cAMP regulation of gene expression during Dictyostelium development. Dev. Biol. 122: 163-171.

Kimmel, A.R. and B. Carlisle. 1986. A gene expressed in undifferentiated vegetative Dictyostelium is repressed by developmental pulses of cAMP and reinduced during differentiation. Proc. Natl. Acad. Sci. 83: 2506-2510.

Kimmel, A.R. and R.A. Firtel. 1983. Sequence organization in Dictyostelium : Unique structure at the $5^{\prime}$-ends of protein coding genes. Nucleic Acids Res. 11: 541-552.

Klein, P.S., T.J. Sun, C.L. Saxe III, A.R. Kimmel, R.L. Johnson, and P.N. Devreotes. 1988. A chemoattractant receptor controls development in Dictyostelium discoideum. Science 241: $1467-1472$.

Knecht, D.A., S.M. Cohen, W.F. Loomis, and H.F. Lodish. 1986 Developmental regulation of Dictyostelium discoideum actin gene fusions carried on low-copy and high-copy transformation vectors. Mol. Cell. Biol. 6: 3973-3983.

Kumagai, A., S.K.O. Mann, M. Pupillo, G. Pitt, P.N. Devreotes, and R.A. Firtel. 1989a. A molecular analysis of $G$ proteins and control of early gene expression by the cell surface cAMP receptor in Dictyostelium. Cold Spring Harbor Symp. Quant. Biol. 53: 675-685.

Kumagai, A., M. Pupillo, R. Gunderson, R. Miake-Lye, P.N. Devreotes, and R. A. Firtel. 1989b. Regulation and function of $\mathrm{G}_{\alpha}$ protein subunits in Dictyostelium. Cell 57: 265-275.

Lacombe, M.-L., G.J. Podgorski, J. Franke, and R.H. Kessin. 1986. Molecular cloning and developmental expression of the cyclic nucleotide phosphodiesterase gene of Dictyostelium discoideum. J. Biol. Chem. 261: 16811-16817.

Lappano, S. and M.B. Coukell. 1982. Evidence that intracellular cGMP is involved in regulating the extracellular cAMP phosphodiesterase and its specific inhibitor in Dictyoste- 
lium discoideum. Dev. Biol. 93: 43-53.

Leichtling, B.H., I.H. Majerfeld, E. Spitz, K.L. Schaller, C. Woffendin, S. Kakinuma, and H.V. Rickenberg. 1984. A cytosolic cyclic AMP-dependent protein kinase in Dictyostelium discoideum. II. Developmental regulation. $J$. Biol. Chem. 259: 661-668.

Majerfeld, I.H., B.H. Leichtling, J.A. Meligeni, E. Spitz, and H.V. Rickenberg. 1984. A cytosolic cyclic AMP-dependent protein kinase in Dictyostelium discoideum. I. Properties. J. Biol. Chem. 259: 654-661.

Mann, S.K.O. and R.A. Firtel. 1987. Cyclic AMP regulation of early gene expression in Dictyostelium discoideum: Mediation via the cell surface cyclic AMP receptor. Mol. Cell. Biol. 7: 458-469.

Mann, S.K.O., S. Datta, P. Howard, A. Hjorth, C. Reymond, C.M. Silan, and R.A. Firtel. 1987. Cyclic AMP regulation of gene expression during Dictyostelium development. In $\mathrm{Mo}$ lecular approaches to developmental biology (eds. R.A. Firtel and E.H. Davidson), pp. 303-328. Alan R. Liss, New York.

Mann, S.K.O., C. Pinko, and R.A. Firtel. 1988. cAMP regulation of early gene expression in signal transduction mutants of Dictyostelium. Dev. Biol. 130: 294-303.

Mann, S.K.O. and R.A. Firtel. 1989. Two-phase regulatory pathway controls cAMP receptor-mediated expression of early genes in Dictyostelium. Proc. Natl. Acad. Sci. 86: 1924-1928.

Mehdy, M.C. and R.A. Firtel. 1985. A secreted factor and cAMP jointly regulate cell-type-specific gene expression in Dictyostelium. Mol. Cell Biol. 5: 705-713.

Mehdy, M.C., D. Ratner, and R.A. Firtel. 1983. Induction and modulation of cell-type-specific gene expression in Dictyostelium. Cell 32: 761-771.

Mellon, P.L., C.H. Clegg, L.A. Correll, and G.S. McKnight. 1989. Regulation of transcription by cyclic AMP-dependent protein kinase. Proc. Natl. Acad. Sci. 86: 4887-4891.

Nellen, W. and R.A. Firtel. 1985. High-copy-number transformants and cotransformation in Dictyostelium. Gene 39: $155-163$.

Nellen, W., C. Silan, and R.A. Firtel. 1984. DNA-mediated transformation in Dictyostelium discoideum: Regulated ex pression of an actin gene fusion. Mol. Cell. Biol. 4: 28902898.

Nellen, W., S. Datta, C. Reymond, A. Silvertsen, S. Mann, T. Crowley, and R.A. Firtel. 1987. Molecular biology in Dictyostelium: Tools and applications. In Methods in cell biology, (ed. J. Spudich), pp. 67-100. Academic Press, Orlando.

Pears, C.J., H.M. Mahbubani, and J.G. Williams. 1985. Characterization of two highly diverged but developmentally coregulated cysteine proteinase genes in Dictyostelium discoideum. Nucleic Acids Res. 13: 8853-8866.

Podgorski, G.J., J. Franke, M. Faure, and R.H. Kessin. 1989. The cyclic nucleotide phosphodiesterase gene of Dictyostelium discoideum utilizes alternate promoters and splicing for the transcription of multiple mRNAs. Mol. Cell. Biol. 9: 39383950.

Poole, S., R.A. Firtel, E. Lamar, and W. Rowekamp. 1981. Sequence and expression of the Discoidin I gene family in Dictyostelium discoideum. I. Mol. Biol. 153: 273-289.

Pupillo, M., A. Kumagai, R.A. Firtel, and P.N. Devreotes. 1989. Multiple $\alpha$ subunits of guanidine nucleotide-binding proteins in Dictyostelium. Proc. Natl. Acad. Sci. 86: 48924896.

Reymond, C.D., R.H. Gomer, W. Nellen, A. Theibert, P. Devreotes, and R.A. Firtel. 1986. Phenotypic changes in- duced by a mutated ras gene during the development of DiCtyostelium transformants. Nature 323: 340-343.

Riabowol, K.T., J.S. Fink, M.Z. Gilman, D.A. Walsh, R.H. Goodman, and J.R. Feramisco. 1988. The catalytic subunit of cAMP-dependent protein kinase induces expression of genes containing cAMP-responsive enhancer elements. $\mathrm{Na}$ ture 336: 83-86.

Rowekamp, W., S. Poole, and R.A. Firtel. 1980. Analysis of multigene family coding the developmentally regulated carbohydrate-binding protein Discoidin-I in $D$. discoideum. Cell 20: 495-505.

Rubino, S., S.K.O. Mann, R.T. Hori, and R.A. Firtel. 1989. Molecular analysis of a developmentally regulated gene required for Dictyostelium aggregation. Dev. Biol. 131: 2736.

Schaap, P. and R. van Driel. 1985. Induction of post-aggregative differentiation in Dictyostelium discoideum by cAMP. Exp. Cell Res. 159: 388-398.

Schaap, P., M.M. van Lookeren Campagne, R. van Driel, P.J.M. van Haastert, and J. Pinas. 1986. Postaggregative differentiation induction by cyclic AMP in Dictyostelium: Intracellular transduction pathway and requirement for additional stimuli. Dev. Biol. 118: 52-63.

Segall, J.E., P.R. Fisher, and G. Gerisch. 1987. Selection of chemotaxis mutants of Dictyostelium discoideum. J. Cell Biol. 104: $151-161$.

Simon, M.-N., D. Driscoll, R. Mutzel, D. Part, J. Williams, and M. Veron. 1989. Overproduction of the regulatory subunit of the cAMP-dependent protein kinase blocks the differentiation of Dictyostelium discoideum. EMBO I. 8: 2039-2043.

Taylor, S.S., J.A. Buechler, L.W. Slice, D.K. Knighton, S. Durgerian, G.E. Ringheim, J.J. Neitzel, W.M. Yonemoto, J.M. Sowadski, and W. Dospmann. 1988. cAMP-dependent protein kinase: A framework for a diverse family of enzymes. Cold Spring Harbor Symp. Quant. Biol. 53: 121-130.

Thiebert, A. and P.N. Devreotes. 1986. Surface receptor-mediated activation of adenylate cyclase in Dictyostelium. $J$. Biol. Chem. 261: 121-125.

van Haastert, P.J.M. 1984. A method for studying cAMP-relay in Dictyostelium discoideum: The effect of temperature on cAMP-relay. I. Gen. Microbiol. 130: 2559-2564.

. 1985. CAMP activates adenylate cyclase and guanylate cyclase of Dictyostelium discoideum cells by binding to different classes of cell-surface receptors. A study with extracellular $\mathrm{Ca}^{2+}$. Biochim. Biophys. Acta 846: 324-333.

Walsh, D.A., J.P. Perkins, and E.G. Krebs. 1968. An adenosine 3', 5'-monophosphate dependent protein kinase from rabbit skeletal muscle. J. Biol. Chem. 243: 3763-3773.

Warrick, H.M. 1987. Codon frequency in Dictyostelium discoideum. In Methods in cell biology, vol. 28: Dictyostelium discoideum: Molecular Approaches to Cell Biology, (ed. J.A. Spudich), pp. 497-500. Academic Press, Orlando, Florida.

Woodford, T.A., L.A. Correll, G.S. McKnight, and J.D. Corbin. 1989. Expression and characterization of mutant forms of the type I regulatory subunit of cAMP-dependent protein kinase: The effect of defective cAMP binding in holoenzyme activation. J. Biol. Chem. 264: 13321-13328.

Yamamoto, K.K., G.A. Gonzalez, W.H. Biggs III, and M.R. Montminy. 1988. Phosphorylation-induced binding and transcriptional efficacy of nuclear factor CREB. Nature 334: 494-498.

Yeh, R.P., F.K. Chan, and M.B. Coukell. 1978. Independent regulation of the extracellular cyclic AMP phosphodiesteraseinhibitor system and membrane differentiation by exogenous cyclic AMP in Dictyostelium discoideum. Dev. Biol. 66: $361-374$. 


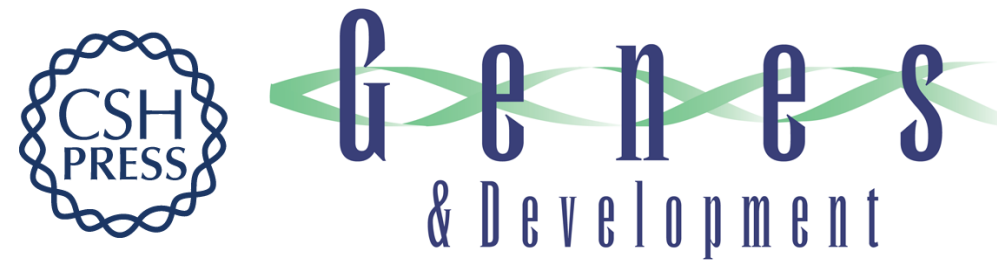

\section{A role for CAMP-dependent protein kinase A in early Dictyostelium development.}

R A Firtel and A L Chapman

Genes Dev. 1990, 4:

Access the most recent version at doi:10.1101/gad.4.1.18

References This article cites 62 articles, 29 of which can be accessed free at:

http://genesdev.cshlp.org/content/4/1/18.full.html\#ref-list-1

License

Email Alerting

Service

Receive free email alerts when new articles cite this article - sign up in the box at the top right corner of the article or click here.

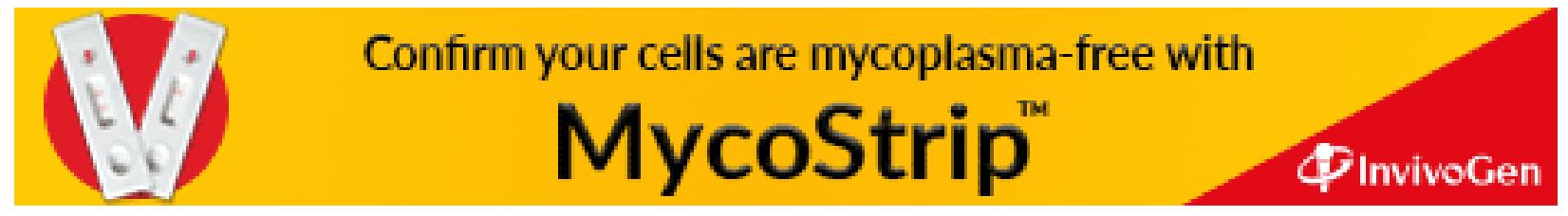

